\title{
Analisa perbandingan kekuatan hasil pengelasan TIG dan pengelasan MIG pada Aluminium 5083
}

\author{
Iswanto $^{1^{\star}}$, Noerdianto ${ }^{2}$, A'rasy Fachruddin $^{3}$, Mulyadi $^{4}$ \\ 1,2,3,4Teknik Mesin, Universitas Muhammadiyah Sidoarjo \\ Jl. Mojopahit 666 B, Sidoarjo, Indonesia \\ *Corresponding author: iswanto.sda@gmail.com
}

\begin{abstract}
This paper will discuss the comparative strength of TIG (Tungsten Inert Gas) welding results and MIG (Metal Inert Gas) welding results. Welding is carried out on aluminium material 5083, by varying the amount of amperage in each type of welding. Amperes variations used in TIG welding and MIG welding are 130 Amperes, 140 Amperes, and 150 Amperes. Furthermore, testing is carried out to determine the strength of the welding results, namely by bending and tensile test. From the bending test results obtained the highest bending strength of $262.36 \mathrm{kgf} / \mathrm{mm}^{2}$, obtained at MIG welding with a strong current used 130 Amperes. The lowest bending strength of $21.61 \mathrm{kgf} / \mathrm{mm}^{2}$, is obtained in TIG welding with the strong current used by 130 Amperes. From the tensile test results obtained the highest tensile strength of $23.48 \mathrm{kgf} / \mathrm{mm}^{2}$, obtained at MIG welding with a strong current used 130 Amperes. The lowest tensile strength of $17.41 \mathrm{kgf} / \mathrm{mm}^{2}$, obtained at TIG welding with a strong current used 130 Amperes.
\end{abstract}

Keywords: TIG welding, MIG welding, Aluminium 5083.

\section{Abstrak}

Tulisan ini akan membahas tentang perbandingan kekuatan hasil pengelasan TIG (Tungsten Inert Gas) dan hasil pengelasan MIG (Metal Inert Gas). Pengelasan dilakukan pada bahan Aluminium 5083, dengan memvariasikan besarnya kuat arus (Ampere) pada masing-masing jenis pengelasan. Variasi kuat arus yang digunakan pada pengelasan TIG dan pengelasan MIG adalah 130 Ampere, 140 Ampere, dan 150 Ampere. Selanjutnya dilakukan pengujian untuk mengetahui kekuatan hasil pengelasan yaitu dengan uji bending dan uji tarik. Dari hasil uji bending diperoleh kekuatan bending tertinggi sebesar 262,36 kgf $/ \mathrm{mm}^{2}$, diperoleh pada pengelasan MIG dengan kuat arus yang digunakan 130 Ampere. Kekuatan bending terendah sebesar $21,61 \mathrm{kgf} / \mathrm{mm}^{2}$, diperoleh pada pengelasan TIG dengan kuat arus yang digunakan 130 Ampere. Dari hasil uji tarik diperoleh kekuatan tarik tertinggi sebesar 23,48 $\mathrm{kgf} / \mathrm{mm}^{2}$, diperoleh pada pengelasan MIG dengan kuat arus yang digunakan 130 Ampere. Kekuatan tarik terendah sebesar $17,41 \mathrm{kgf} / \mathrm{mm}^{2}$, diperoleh pada pengelasan TIG dengan kuat arus yang digunakan 130 Ampere.

Kata kunci: Pengelasan TIG, pengelasan MIG, Aluminium 5083.

\section{Pendahuluan}

Untuk membuat kapal cepat dibutuhkan material yang kuat, ringan dan tahan terhadap korosi, untuk itu dipilih bahan Aluminium karena memenuhi kriteria yang dibutuhkan. Bahan utama yang digunakan adalah Aluminium 5083 H116 MG TH tebal $6 \mathrm{~mm}$. Aluminium 5083 sangat tahan korosi terhadap serangan oleh air laut dan lingkungan kimia industri [1]. Pada proses penyambungannya dipilih proses pengelasan, karena memiliki lebih banyak keunggulan dibanding dengan proses yang lain.

Proses pengelasan untuk penyambungan Aluminium ada beberapa jenis, diantaranya adalah las MIG (Metal 
Inert Gas) dan las TIG (Tungsten Inert Gas). Las MIG digunakan untuk menyambung dek kapal dengan rangka kapal, sedangkan teknik pengelasan yang digunakan pada pengelasan dek kapal adalah teknik pengelasan vertikal (3 grove). Las TIG digunakan sebagai pengelasan kerangka dalam dek kapal dan interior. Kedua jenis pengelasan tersebut memiliki tingkat efisiensi yang berbeda, waktu dan proses pengelasan juga berbeda [2].

Pada penelitian ini akan dibahas bagaimana perbandingan kekuatan antara hasil pengelasan TIG dan hasil dari pengelasan MIG. Serta bagaimana pengaruh variasi kuat arus yang berbeda pada masing-masing jenis pengelasan terhadap kekuatan hasil pengelasannya.

\section{Tinjauan Pustaka}

\section{Las TIG}

Pengelasan TIG merupakan las busur gas dengan elektroda tak terumpan, sebagaimana gas akan disemburkan ke area las untuk melindungi busur dan logam yang mencair terhadap atmosfir, umumnya gas yang digunakan yaitu gas Argon (Ar) atau gas Helium $(\mathrm{He})$ sedangkan elektroda yang di gunakan adalah batang wolfram yang dapat menghasilkan busur listrik yang tidak bisa mencair. Untuk menghasilkan busur listrik, digunakan elektroda yang tidak terkonsumsi terbuat dari logam tungsten atau yang memiliki titik lebur sangat tinggi [2][3][9]. Skema proses pengelasan TIG dapat dilihat seperti pada Gambar 1.

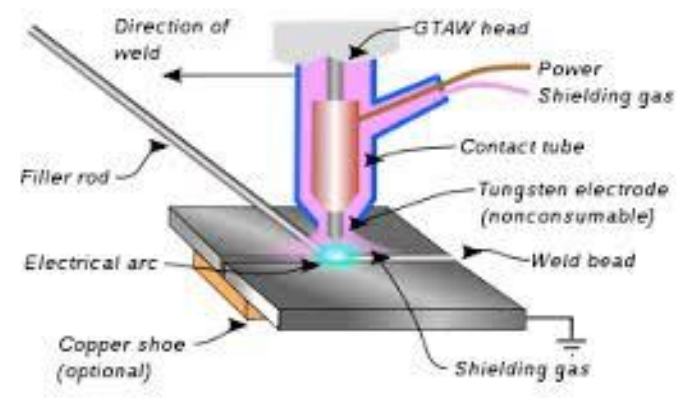

Gambar 1. Skema pengelasan TIG [4]

\section{Las MIG}

Las MIG adalah proses pengelasan dimana gas akan disemburkan ke area yang di las untuk melindungi busur. Gas yang digunakan adalah gas yang tidak mudah bereaksi terhadap udara ataupun logam yang mencair, seperti gas argon dan helium, untuk busur terkadang $\mathrm{O}_{2}$ antara $2 \%$ sampai $5 \%$ atau $\mathrm{CO}_{2}$ antara $5 \%-20 \%$ [5][6]. Skema dari proses pengelasan MIG ditunjukkan dalam Gambar 2.

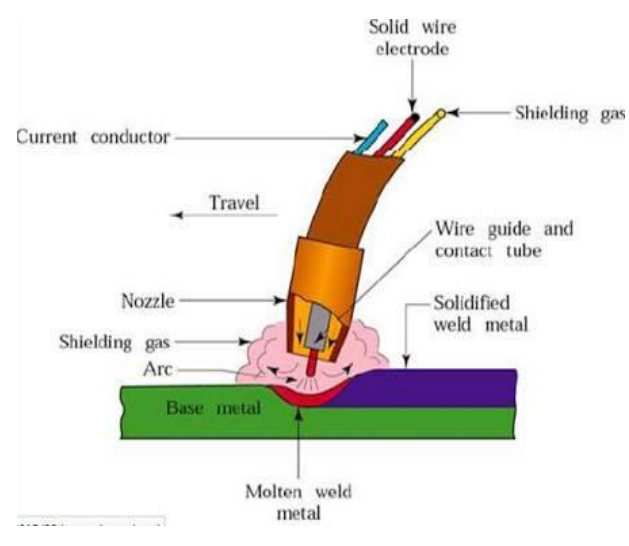

Gambar 2. Skema pengelasan MIG [5]

3. Pengujian Bending

Uji bending bisa juga disebut dengan pengujian lengkung biasanya di lakukan untuk menentukan flexural strength komponen. Pengujian ini dilakukan dengan menumpu batang dengan tumpuan sederhana dan kemudian membebani batang tersebut secara transversal pada bagian tengahnya [7]. Bila materialnya ulet, kegagalan yang terjadi berupa luluh sedangkan bila materialnya getas kegagalannya adalah berupa patahan.

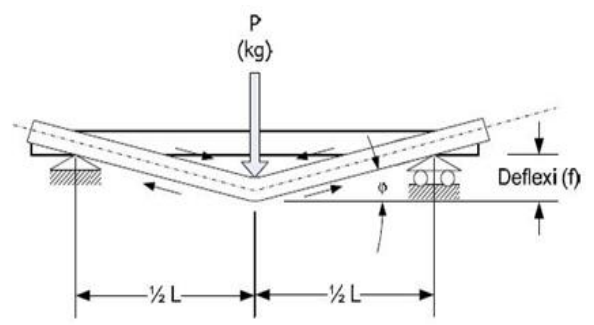

Gambar 3. Pengaruh pembebanan terhadap benda uji.

\section{Pengujian Tarik}

Pengujian tarik dilakukan untuk mengetahui kekuatan sambungan logam yang telah dilas, karena mudah dilakukan, 
dan menghasilkan tegangan seragam (uniform) pada penampangnya. Sifat-sifat bahan yang didapat dari hasil pengujian tarik dirumuskan seperti berikut [8]:

$$
\sigma u=\frac{F_{u}}{A_{o}}
$$

Keterangan:

$\sigma_{\mathrm{u}}=$ Tegangan tarik $\left(\mathrm{kgf} / \mathrm{mm}^{2}\right)$ atau $(\mathrm{MPa})$

$\mathrm{F}_{\mathrm{u}}=$ Gaya tarik maksimum $(\mathrm{N})$

$\mathrm{A}_{\mathrm{o}}=$ Luas penampang awal spesimen $\left(\mathrm{mm}^{2}\right)$

Regangan (persentase pertambahan panjang) yang dihasilkan dari membagi perpanjangan panjang ukur $(\Delta \mathrm{L})$ dengan panjang ukuran awal spesimen:

$$
\varepsilon=\frac{\Delta L}{L_{o}} \times 100 \%=\frac{L-L o}{L o} \times 100 \%
$$

Keterangan:

$\mathrm{E}=$ Regangan $(\%)$

$\mathrm{L}=$ Panjang akhir setelah patah $(\mathrm{mm})$

Lo $=$ Panjang awal spesimen $(\mathrm{mm})$

\section{Metode Penelitian}

Peralatan yang digunakan adalah mesin las TIG AC dan las MIG DC dengan polaritas balik (+). Elektroda yang digunakan Elektroda AWS A/SFA 5.10 88 ER $5183 \varnothing 1.20 \mathrm{~mm}$ dan AWS TIG ROD ER5356 $2.4 \mathrm{~mm}$. Plat Aluminium dipotong menggunakan mesin gerinda sesuai ukuran spesimen yang akan dilas dan permukaan plat di amplas menggukan paper (amplas gerinda).

Selanjutnya dilakukan pengelasan TIG menggunakan elektroda AWS TIG ROD ER5356 $2.4 \quad \mathrm{~mm}$. Hasil pengelasannya seperti pada Gambar 4.

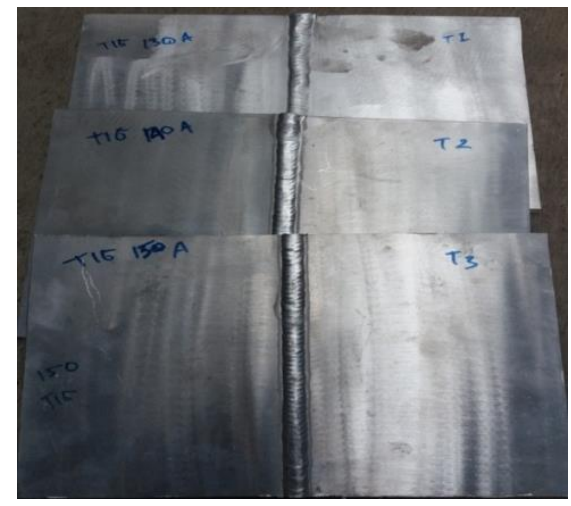

Gambar 4. Hasil proses pengelasan TIG.
Kemudian melakukan proses pengelasan MIG menggunakan elektroda AWS A/SFA 5.10 - 88 ER 5183 $\varnothing 1.20 \mathrm{~mm}$. Hasil pengelasan MIG dapat dilihat pada Gambar 5. Setelah itu dibuat spesimen untuk dilakukan pengujian bending dan pengujian tarik.

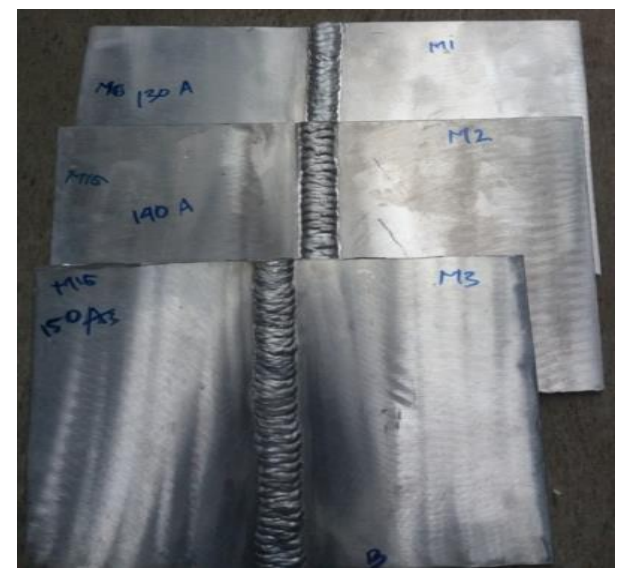

Gambar 5. Hasil proses pengelasan MIG.

\section{Hasil dan Pembahasan}

1. Pengujian Bending.

Dari pengujian bending terhadap spesimen logam Aluminium 5083 dengan menggunakan proses pengelasan TIG dan MIG disajikan pada Tabel 1.

Tabel 1. Data hasil pengujian bending.

\begin{tabular}{cccc}
\hline $\begin{array}{c}\text { Proses } \\
\text { pengelasan }\end{array}$ & $\begin{array}{c}\text { Kuat } \\
\text { arus } \\
\text { (Ampere) }\end{array}$ & $\begin{array}{c}\text { Kekuatan } \\
\text { Bending } \\
\left(\mathrm{kgf} / \mathrm{mm}^{2}\right)\end{array}$ & $\begin{array}{c}\text { Regangan } \\
(\%)\end{array}$ \\
\hline \multirow{3}{*}{ TIG } & 130 & 21,61 & 12,87 \\
\cline { 2 - 4 } & 140 & 24,92 & 21,05 \\
\cline { 2 - 4 } & 150 & 25,03 & 25,19 \\
\hline \multirow{3}{*}{ MIG } & 130 & 262,36 & 33,92 \\
\cline { 2 - 4 } & 140 & 260,85 & 36,14 \\
\cline { 2 - 4 } & 150 & 254,15 & 39,30 \\
\hline
\end{tabular}

Dari Tabel 1 menunjukkan bahwa kekuatan bending tertinggi diperoleh dari proses pengelasan MIG dengan kuat arus 130 Ampere dan kekuatan bending semakin menurun seiring dengan semakin besarnya kuat arus yang digunakan. Kekuatan bending terendah diperoleh dari proses pengelasan TIG dengan kuat arus 130 Ampere dan kekuatan bending semakin naik seiring dengan naiknya kuat 
arus yang digunakan pada proses pengelasan.

Regangan terbesar dihasilkan pada pengelasan MIG menggunakan kuat arus 150 Ampere dan regangan semakin kecil seiring dengan semakin menurunnya kuat arus yang digunakan pada proses pengelasan. Regangan terkecil didapatkan pada proses pengelasan TIG dengan kuat arus yang digunakan sebesar 130 Ampere dan regangan semakin besar seiring dengan semakin tingginya kuat arus yang digunakan pada proses pengelasan.

Adapun kondisi spesimen setelah dilakukan uji bending seperti terlihat pada Gambar 6 dan 7.

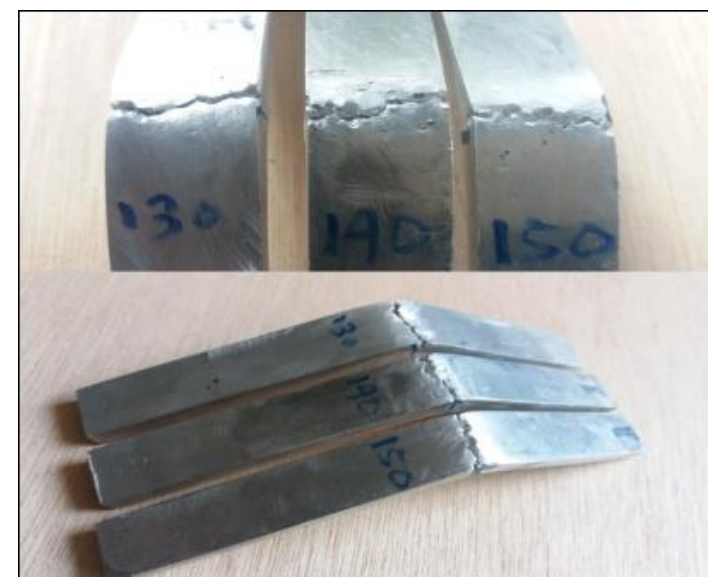

Gambar 6. Spesimen las TIG setelah uji bending.

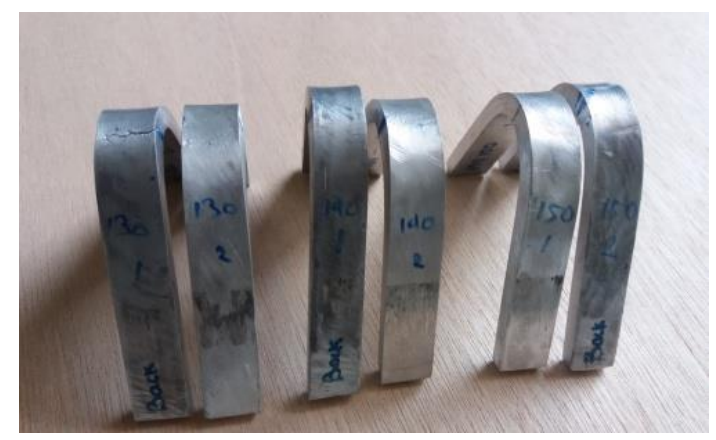

Gambar 7. Spesimen las MIG setelah uji bending.

\section{Pengujian Tarik}

Dari pengujian tarik terhadap spesimen logam Aluminium 5083 dengan menggunakan proses pengelasan TIG dan MIG diperoleh data seperti yang ditampilkan pada Tabel 2.
Tabel 2. Data hasil pengujian tarik.

\begin{tabular}{cccc}
\hline $\begin{array}{c}\text { Proses } \\
\text { pengelasan }\end{array}$ & $\begin{array}{c}\text { Kuat } \\
\text { arus } \\
\text { (Ampere) }\end{array}$ & $\begin{array}{c}\text { Tegangan } \\
\text { tarik } \\
\left(\mathrm{kgf} / \mathrm{mm}^{2}\right)\end{array}$ & $\begin{array}{c}\text { Regangan } \\
(\%)\end{array}$ \\
\hline \multirow{3}{*}{ TIG } & 130 & 17,41 & 8,19 \\
& 140 & 17,47 & 9,41 \\
& 150 & 18,95 & 11,15 \\
MIG & 130 & 23,48 & 16,12 \\
& 140 & 21,12 & 16,76 \\
& 150 & 20,61 & 16,55 \\
\hline
\end{tabular}

Dari data pada Tabel 2 dapat disajikan dalam bentuk grafik hubungan antara tegangan dan regangan seperti pada Gambar 8 dan 9.

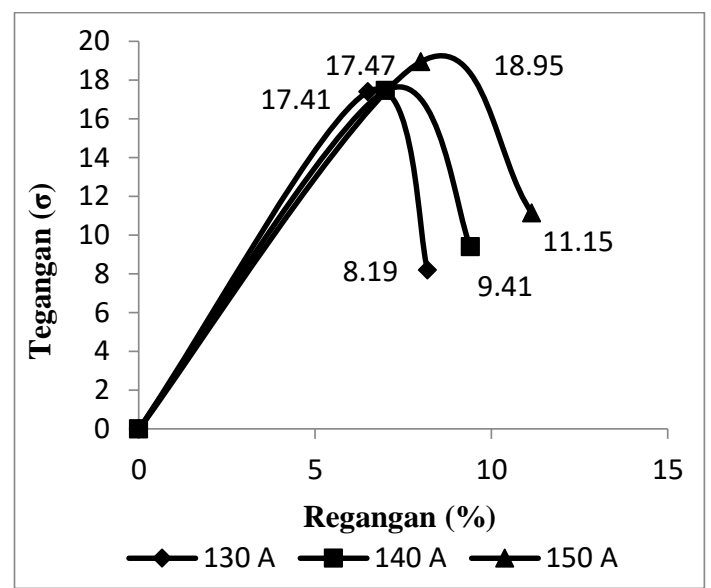

Gambar 8. Grafik Tegangan dan Regangan Pengujian Tarik Pengelasan TIG

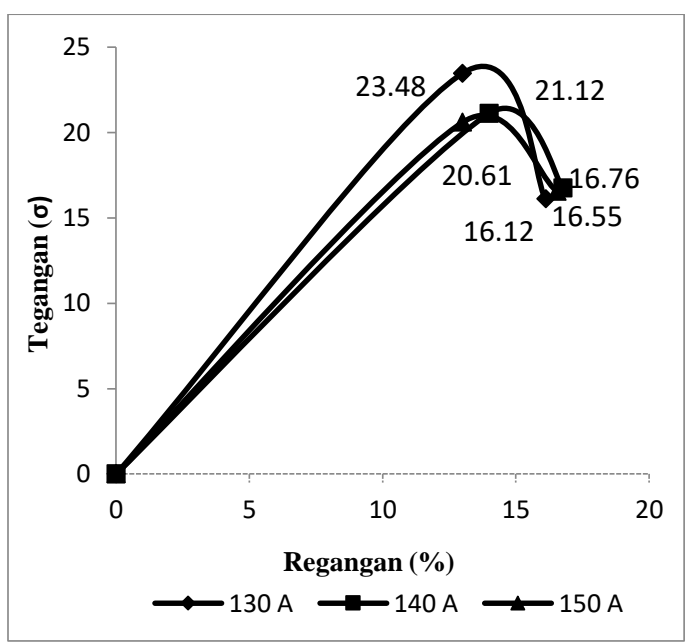

Gambar 9. Grafik Tegangan dan Regangan Pengujian Tarik Pengelasan MIG

Dari Tabel 2 serta Gambar 8 dan 9 menunjukkan bahwa kekuatan tarik tertinggi diperoleh pada proses pengelasan MIG yang menggunakan kuat arus 130 
Ampere dan kekuatan tarik semakin menurun seiring dengan semakin naiknya kuat arus yang digunakan. Kekuatan tarik terendah diperoleh dari proses pengelasan TIG dengan kuat arus 130 Ampere dan kekuatan tariknya semakin naik seiring dengan semakin naiknya kuat arus yang digunakan pada proses pengelasan.

Regangan terbesar didapatkan pada proses pengelasan MIG dengan menggunakan kuat arus sebesar 140 Ampere. Regangan terkecil diperoleh pada proses pengelasan TIG dengan kuat arus yang digunakan 130 Ampere dan regangan semakin besar seiring dengan naiknya kuat arus yang digunakan pada proses pengelasan.

Adapun kondisi spesimen setelah dilakukan uji tarik seperti terlihat pada Gambar 10 dan 11.

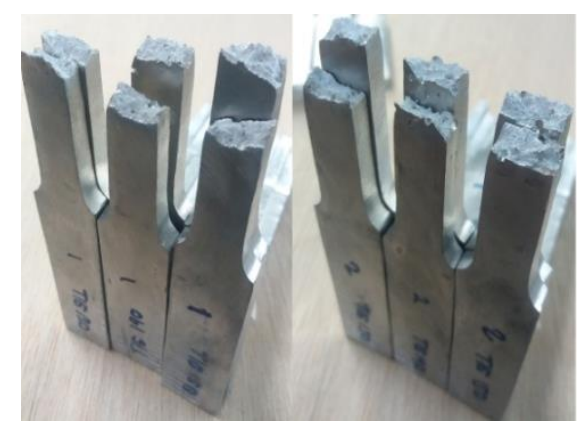

Gambar 10. Spesimen las TIG setelah uji tarik

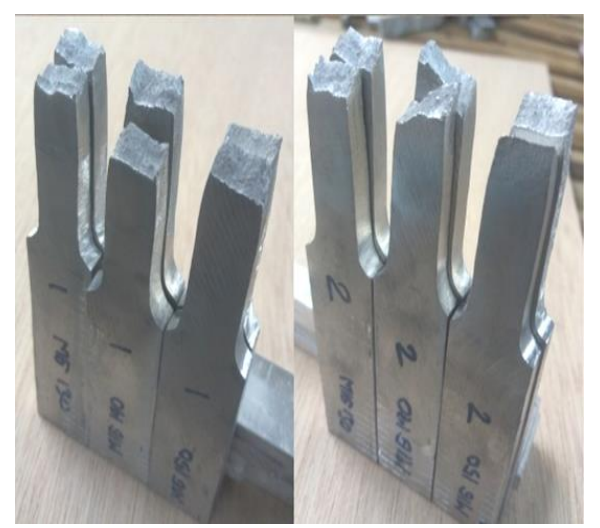

Gambar 11. Spesimen las MIG setelah uji tarik

\section{Kesimpulan}

Kekuatan bending dan kekuatan tarik hasil pengelasan menggunakan las MIG lebih besar dibandingkan dengan menggunakan las TIG.
Pada las TIG, kekuatan tarik dan kekuatan bending terbesar diperoleh pada penggunaan kuat arus yang besar. Sedangkan pada las MIG, kekuatan tarik dan kekuatan bending terbesar diperoleh pada penggunaan kuat arus yang kecil. Regangan yang dihasilkan dari proses pengelasan MIG lebih besar dibandingkan dengan hasil dari pengelasan TIG. Pada las TIG dan las MIG, regangan terbesar didapatkan pada pemakaian kuat arus yang besar.

\section{Referensi}

[1]. Dewanto, A.P. dkk., 2016. Analisa kukuatan mekanik sambungan las metode MIG (metal inert gas) dan metode FSW (friction stir welding) 800 rpm pada Aluminium tipe 5083. Jurnal Teknik Perkapalan. vol. 4, no. 3, hal. 613-631.

[2]. Kou, Sindo, 2003. Welding Metallurgy, $2^{\text {nd }}$ Ed., A John Wiley \& Sons, Inc., New Jersey, Canada.

[3]. Syahrani, A. Dkk., 2017. Pengaruh variasi arus pengelasan GTAW terhadap sifat mekanis pada pipa baja karbon ASTM A 106. Jurnal Mekanikal. vol. 8, no.1, hal. 721729.

[4]. Informasi dari https://www.weldingis.com/gtawwelding/ (diakses pada 30 Maret 2020)

[5]. Mathers Gene, 2002. The Welding of Aluminium and its alloys, CRC Press, Washington.

[6]. Darsin, M. Dkk., 2010. Analisa sifat mekanik dan struktur mikro paduan Aluminium 5083 akibat pengelasan metal inert gas (MIG) dengan variasi preheat dan post heat. Jurnal ROTOR. vol. 3, no. 2, hal. 67-74.

[7]. Naharuddin, Dkk., 2015. Kekuatan tarik dan bending sambungan las pada material baja SM 490 dengan metode pengelasan SMAW dan SAW. Jurnal Mekanikal. vol. 6, no. 1, hal. 551-555. 
[8]. Hermanto, Aris dan Iswanto, 2018. Pengaruh flux elektroda AWS 5.1 E 6013 dicelup oli pada pengelasan besi cor kelabu FC-25 terhadap kekuatan tarik. Jurnal REM. vol. 3, no. 2, hal. 57-60.

[9]. Budiyanto, E., Nugroho, E., \& Masruri, A. (2017). Pengaruh diameter filler dan arus pada pengelasan TIG terhadap kekuatan tarik dan struktur mikro pada baja karbon rendah. Turbo: Jurnal Program Studi Teknik Mesin, 6(1). 